\title{
Beneficial effect of successful simultaneous pancreas-kidney transplantation on plasma profile of metalloproteinases in type 1 diabetes mellitus patients
}

Jerzy Chudek ( $\nabla$ chj@poczta.fm )

Śląski Uniwersytet Medyczny w Katowicach https://orcid.org/0000-0002-6367-7794

Aureliusz Kolonko

Śląski Uniwersytet Medyczny w Katowicach

Jacek Ziaja

Śląski Uniwersytet Medyczny w Katowicach

Tomasz Francuz

Śląski Uniwersytet Medyczny w Katowicach

Dorota Kamińska

Uniwersytet Medyczny im Piastow Slaskich we Wroclawiu

Aleksander Owczarek

Śląski Uniwersytet Medyczny w Katowicac

Piotr Kuczera

Śląski Uniwersytet Medyczny w Katowicach

Agata Kujawa-Szewieczek

Śląski Uniwersytet Medyczny w Katowicach

Mariusz Kusztal

Uniwersytet Medyczny im Piastow Slaskich we Wroclawiu

Adrian Kowalik

Śląski Uniwersytet Medyczny w Katowicach

Dominika Bożek-Pająk

Śląski Uniwersytet Medyczny w Katowicach

Joanna Kluz

Uniwersytet Medyczny im Piastow Slaskich we Wroclawiu

Piotr Choręza

Śląski Uniwersytet Medyczny w Katowicach

Robert Król

Śląski Uniwersytet Medyczny w Katowicach

Magdalena Krajewska

Uniwersytet Medyczny im Piastow Slaskich we Wroclawiu

Lech Cierpka

Śląski Uniwersytet Medyczny w Katowicach

Andrzej Więcek

Śląski Uniwersytet Medyczny w Katowicach

Original investigation 
Keywords: type 1 diabetes, simultaneous pancreas kidney transplantation, matrix metalloproteinases, pulse wave velocity, arterial stiffness, intima-media thickness

Posted Date: July 24th, 2020

DOI: https://doi.org/10.21203/rs.3.rs-42379/v1

License: (c) (i) This work is licensed under a Creative Commons Attribution 4.0 International License. Read Full License

Version of Record: A version of this preprint was published at Journal of Clinical Medicine on August 25th, 2021. See the published version at https://doi.org/10.3390/jcm10173800. 


\section{Abstract \\ Background}

It is virtually unknown whether the restoring of normal glucose metabolism after successful simultaneous pancreas-kidney transplantation (SPK) improves vascular wall morphology and function in type 1 diabetic (T1D) patients. This study has been aimed to compare arterial stiffness, assessed by pulse wave velocity (PWV), carotid intima-media thickness (IMT) biomarkers of arterial wall calcification, and parameters of calcium-phosphate metabolism in T1D patients after SPK or kidney transplantation alone (KTA).

\section{Methods}

In 39 SPK and 39 KTA adult patients of similar age, PWV and IMT were measured at a median of 83 (62-109) months posttransplantation. Additionally, carotid plaques were visualized and semi-qualitatively classified. Circulating matrix metalloproteinases (MMPs), calcification biomarkers, and calcium-phosphate metabolism parameters were measured.

\section{Results}

Although PWV and IMT values were similar, the occurrence of atherosclerotic plaques (51.3 vs. $70.3 \%, p<0.01)$, turned to be lower, especially in case of calcified lesions (35.9 vs. $64.9 \%, p<0.05)$ in patients after SPK. There were significantly lower concentrations of MMP-1, MMP-2, MMP-3 and osteocalcin (OC) in SPK subjects. Among the analyzed biomarkers, only log MMP-1, log MMP-2 and log MMP-3 concentrations were associated with $\log \mathrm{HbA}_{1 \mathrm{c}}$. In addition, both $\log \mathrm{MMP}-1$ and $\log$ MMP-3 were inversely related to estimated glomerular filtration rate (eGFR). Multivariate stepwise backward regression analysis revealed that MMP- 1 and MMP-3 variability were explained only by $\log \mathrm{HbA}_{1 \mathrm{c}}$, whereas OC variability only by eGFR.

\section{Conclusion}

Normal glucose metabolism achieved by simultaneously transplanted pancreas in T1D renal transplant recipients is followed by the favorable profile of circulating matrix metalloproteinases, which may reflect the vasoprotective effect of SPK.

\section{Background}

Simultaneous pancreas and kidney transplantation (SPK) is the treatment of choice in patients with type 1 diabetes (T1D) and end-stage renal disease (ESRD). This procedure results in improved T1D patient survival as compared to kidney transplant alone (KTA) [1], even in case of those who received organs from living donors [2]. Moreover, SPK patients have lower blood pressure, better left ventricular function and better cardiovascular outcomes $[3,4]$. It is worth to noting that both chronic kidney disease (CKD) and T1D are associated with increased arterial stiffness and progression of atherosclerosis in a time-dependent manner [5-7]. What appears important, both large-vessel atherosclerosis and medial calcification are highly prevalent in this population and contribute to arterial wall dysfunction $[5,6,8]$. It was previously shown that microvascular damage, measured in the oral mucosa, is reversed early after successful SPK [9]. In our previous study, the endothelial function assessed by brachial flow-mediated dilation and plasma nitrites level was more improved in SPK recipients than in KTA patients [10]. However, both the arterial stiffness measured by pulse wave velocity (PWV) and the levels of serological markers of endothelial dysfunction were still elevated in a mid-term observation after successful SPK [11]. In observational studies, a slower progression of macrovascular disease was observed after SPK, as compared with KTA, especially in the longer, 10-year follow-up period [12]. In line with that, the survival advantage attributed to the effect of restoring normoglycemia in T1D patients seems to be more likely demonstrated only in a sufficiently long follow-up period 
[13]. One could expect that the vasoprotective effect of the normoglycemia restoration should be detectable much earlier by analyzing markers on vascular remodeling in circulation. However, there is no data demonstrating whether long-term better glycemic control after successful SPK improves vascular wall morphology in T1D patients.

The matrix metalloproteinases (MMPs) family is a bundle of zinc-dependent proteases that are involved in the degradation and hydrolysis of extracellular matrix components [14]. Their activity contributes to all phases of vascular remodeling, especially in the diabetic and uremic milieu $[14,15]$. In T1D patients, some of MMPs were shown to be associated with arterial stiffness and pulse pressure [16], as well as cardiovascular events and all-cause mortality [17]. It has also been demonstrated that several MMPs may initiate vascular calcifications or accelerate this process $[18,19]$.

The present study is aimed to compare arterial stiffness, intima-media thickness and several arterial wall calcification biomarkers, as well as calcium-phosphate metabolism parameters in T1D patients long-term after SPK transplantation or KTA.

\section{Methods}

Hereby we present the results of cross-sectional study in kidney transplant recipients, performed in two Polish transplant centers (in Katowice and Wrocław) between 2014 and 2017. The study protocol was approved by Bioethics Committee of the Medical University of Silesia in Katowice (KNW/0022/KB1/151/12) and each participant gave informed consent. Clinical data were obtained from a database of transplant center and from original medical records. The following were provided: donor data (age, cause of death), recipient data (gender, age, body mass index- BMl, duration of diabetes, dialysis vintage and follow-up period, smoking status, co-medication with immunosuppressive agents, glucocorticoids, and statins.

\section{Study group}

Two groups of T1D patients after SPK $(n=39)$ or KTA $(n=39)$, with a minimum post-transplant follow-up period of 12 months, were enrolled into the study. In all patients, type 1 diabetes requiring insulin therapy was diagnosed in childhood or adolescence, and ESRD developed as a consequence of diabetic nephropathy. T1D groups did not differ in terms of recipient's gender, BMI, duration of pre-transplant diabetes mellitus, and dialysis vintage, whereas the age difference was of borderline significance $(p=0.06)$.

The exclusion criteria were as follows: a pre-emptive and living donor, second or third kidney transplantation, significantly impaired kidney graft function at the time of the study with estimated glomerular filtration rate (eGFR) $\leq 30 \mathrm{ml} / \mathrm{min} / 1.73 \mathrm{~m}{ }^{2}$ (calculated according to MDRD formula), bacterial infection within 1 month preceding the study, diagnosis of cancer or liver cirrhosis, apparent noncompliance, and additionally any type of antidiabetic medication used in SPK recipients.

In all patients, the kidney was transplanted on standard basis, and in SPK recipients the pancreatic graft was placed intraperitoneally, with systemic drainage of venous blood and enteric drainage of pancreatic juice.

\section{Carotid artery intima-media thickness (IMT) and carotid plaques assessment}

Carotid ultrasound examination was performed using a Siemens machine (Sonoline Antares, Mountain View, CA) equipped with a 4.0-9.0 MHz linear transducer. The evaluation comprised the common, internal, and external carotid arteries and the carotid bifurcation on each side. The common carotid artery IMT was measured proximal to the carotid bulb, almost every $1 \mathrm{~cm}$, omitting visible plaques. The results from three separate measurements on each side were then averaged. Additionally, at each examined location, the vessels were carefully evaluated concerning the presence of plaques, which was classified based on the following simplified scale: 0- no lesions, 1- non-calcified lesions, 2- at least one calcified lesion, 3- some calcified lesions, and 4- carotid bulb heavily covered with calcified lesions. The final plaque score was equal to the higher score obtained for both sides. 


\section{Carotid-femoral pulse wave velocity (PWV)}

Arterial stiffness measurements were performed in the morning, after at least 15 minutes of rest in the supine position, using a non-invasive tonometer (Sphygmo-Cor 2000, AtCor Medical, Sydney, Australia), placed over the carotid and femoral arteries. Pressure signals were calibrated using brachial blood pressure, and PWV was calculated as the time of pulse wave between the diagnosed points [distance $(\mathrm{m}) /$ time $(\mathrm{s})$ ].

\section{Laboratory measurements}

The concentrations of blood glycated hemoglobin $\left(\mathrm{HbA}_{1 \mathrm{c}}\right)$, serum creatinine, lipids, calcium, and phosphate were routinely measured during standard visit in the out-patient clinic. Additionally, blood samples were collected from each patient in a closed system into tubes containing citrate and ethylenediaminetetraacetic acid (EDTA) from each patient. The tubes were allowed to remain standing for $30 \mathrm{~min}$ at room temperature, then they were centrifuged (for $15 \mathrm{~min}$., $3000 \mathrm{rpm}$ ), and finally preserved at $-70^{\circ} \mathrm{C}$.

Enzyme-linked immunosorbent assays (ELISA) using commercially available kits were applied for: plasma concentration measurements of fetuin A (Biovendor, Modřice, Czech Republic; with limit of quantification (LoQ) of $0.1 \mathrm{ng} / \mathrm{ml}$, intra-assay variation < 3.6\%, inter-assay variation <6.3\%), high-sensitivity C-reactive protein - (CRP) (Immundiagnostic AG, Bensheim, Germany; with LoQ of $0.09 \mathrm{mg} / \mathrm{l}$, intra-assay variation $<6 \%$, inter-assay variation $<11.6 \%$ ), osteoprotegerin (OPG) (Biovendor, Modřice, Czech Republic; with LoQ of 0.03 umol/I, intra-assay variation $<4.9 \%$, inter-assay variation $<9.0 \%$ ), matrix

metalloproteinase 9 (MMP-9) (Biovendor, Modřice, Czech Republic; with LoQ of $0.05 \mathrm{ng} / \mathrm{ml}$, intra-assay variation $<7.3 \%$, interassay variation $<10.2 \%$ ), fibroblast growth factor-23 (FGF23) (Immutopics, San Clemente, CA, U.S., with intra-assay variation $<4.4 \%$ and inter-assay variation < 6.1\%), and soluble a-Klotho (Immuno-Biological Laboratories Co. Ltd; Fujioka-Shi, Gunma, Japan; with intra-assay variation $<3.0 \%$ and inter-assay variation $<6.5 \%)$. Plasma 25 -hydroxylated vitamin D (25-OH-D) (LoQ $3 \mathrm{ng} / \mathrm{ml}$ ) and intact parathyroid hormone (PTH) levels were assessed by electrochemiluminescence method (ECLIA), using commercially available kits in Cobas E411 analyzer (Roche Diagnostics $\mathrm{GmbH}$, Mannheim, Germany) with inter-assay coefficients of variability of $<7.8$ and $<6.5 \%$, respectively.

Plasma levels of matrix metalloproteinases (MMP-1, MMP-2, and MMP-3), osteocalcin (OC), and osteopontin (OP) were measured using multiplex Bio-Plex ${ }^{\circledR}$ kits (Bio-Rad, CA, USA), in accordance with the manufacturer's instructions. Median bead fluorescence readings were taken using the Bio-Plex 200 System with high PMT (High RP1) setting and analyzed with Bio-Plex Manager version 6.1.0.727 (Bio-Rad Laboratories).

\section{Data analysis}

Blood pressure (BP) was measured at the beginning of study, three times in the sitting position at the arm without arteriovenous fistula. Patients with BP values above $140 / 90 \mathrm{mmHg}$ or those who received antihypertensive medication were diagnosed as hypertensive.

Vitamin D status was categorized by commonly used cut-offs and definitions of serum 25-OH-D: the values below $10 \mathrm{ng} / \mathrm{mL}$ were categorized as severely deficient, between 10 and $19.9 \mathrm{ng} / \mathrm{mL}$ as deficient, between 20 and $29.9 \mathrm{ng} / \mathrm{mL}$ as insufficient, and those with values equal to or above $30 \mathrm{ng} / \mathrm{mL}$ as sufficient 25-OH-D concentrations (20).

The kidney graft function was measured using eGFR calculated according to MDRD formula.

\section{Statistical analysis}

Statistical analysis was performed using STATISTICA 13.0 PL (TIBCO Software Inc., Palo Alto, CA, U.S.), StataSE 12.0 (StataCorp LP, TX, U.S.), and R software [R Core Team (2013). R: A language and environment for statistical computing. R Foundation for Statistical Computing, Vienna, Austria. URL http://www.R-project.org/]. The level of statistical significance was set at $p$ value below 0.05 . All tests were two-tailed. Imputations were not performed for a few missing clinical data. Nominal and ordinal data were expressed as percentages, whilst interval data were expressed as mean value \pm standard 
deviation (SD) in case of normal distribution, or as median with lower and upper quartile in case of data with skewed or nonnormal distribution. The distribution of variables was evaluated by the Shapiro-Wilk test, and the homogeneity of variances was assessed by Levene test.

To compare data between analyzed groups, t-Student test was used. In case of skewed distribution, normalization with logarithmic function was performed. Categorical variables were compared using either $\chi^{2}$ tests or $\chi^{2}$ tests with Yates correction.

In order to assess the relationship between variables, linear regression was used. Multivariate models included variables selected on the basis of univariable regression analyses. Cook-Weisberg test and Cameron \& Trivedi's decomposition test were used to test the residuals for heteroscedasticity as well as the violation of skewness and kurtosis assumptions in linear regression. The correlation between variables was assessed either with Pearson linear correlation coefficient or Spearman rank correlation coefficient, depending on data distribution.

\section{Results}

\section{Study groups characteristics}

The characteristics of SPK and KTA groups are given in Table 1. There was no significant difference in post-transplant follow-up period between these groups [Me: 80 (67-110) vs. Me: 86 (47-106) months, respectively; NS]. As expected, SPK patients showed markedly lower $\mathrm{HbA}_{1 \mathrm{c}}$ levels. In addition, the proportion of patients with $\mathrm{HbA}_{1 \mathrm{c}}$ in the reference range for healthy individuals (below 5.5\%) was significantly higher in SPK than in KTA group (61.5 vs. 0\%, respectively; $p<0.001$ ). Patients in SPK group had higher eGFR values. Of note, this group presented a slightly, but significantly higher high-density lipoprotein (HDL)-cholesterol level (not corresponding with the frequency of statin usage) and lower level of triglycerides (TG). The plasma levels of CRP were comparable in both study groups. 
Table 1

Basic characteristics of both study groups (SPK and KTA).

\begin{tabular}{|c|c|c|c|}
\hline & SPK & KTA & $\mathrm{p}$ \\
\hline & $n=39$ & $n=39$ & \\
\hline Sex (male) [n (\%)] & $17(43.6)$ & $17(43.6)$ & 1.00 \\
\hline Age at the time of study [years] & $44(40-51)$ & $49(42-56)$ & 0.06 \\
\hline Total duration of diabetes [years] & $26 \pm 6$ & $29 \pm 7$ & 0.10 \\
\hline Duration of dialysis therapy prior transplant [months] & $17.0(11.0-27.0)$ & $23.5(14.0-35.0)$ & 0.13 \\
\hline Follow-up after transplant [months] & $87.9 \pm 36.1$ & $84.5 \pm 41.0$ & 0.70 \\
\hline BMI $\left[\mathrm{kg} / \mathrm{m}^{2}\right]$ & $22.6 \pm 3.0$ & $23.8 \pm 3.6$ & 0.11 \\
\hline Active smokers [n (\%)] & $6(15.4)$ & 0 & $<0.05$ \\
\hline $\mathrm{HbA}_{1 \mathrm{c}}[\%]$ & $5.37(5.06-5.75)$ & $7.70(6.70-8.43)$ & $<0.001$ \\
\hline eGFR $\left[\mathrm{ml} / \mathrm{min}^{\prime} 1.73 \mathrm{~m}^{2}\right]$ & $62.9 \pm 24.1$ & $48.7 \pm 16.4$ & $<0.01$ \\
\hline Total cholesterol [mmol/L] & $4.96 \pm 1.06$ & $5.21 \pm 1.01$ & 0.30 \\
\hline LDL-cholesterol [mmol/L] & $3.18 \pm 0.80$ & $3.10 \pm 1.04$ & 0.72 \\
\hline HDL-cholesterol [mmol/L] & $1.69 \pm 0.39$ & $1.50 \pm 0.42$ & $<0.05$ \\
\hline Triglycerides [mmol/L] & $0.91(0.50-1.25)$ & $1.33(1.07-1.70)$ & $<0.05$ \\
\hline Statins $[\mathrm{n}(\%)]$ & $8(20.5)$ & $15(38.5)$ & 0.08 \\
\hline Total calcium [mmol/L] & $2.35 \pm 0.13$ & $2.41 \pm 0.14$ & $<0.05$ \\
\hline Phosphorus [mmol/L] & $1.11 \pm 0.26$ & $1.08 \pm 0.18$ & 0.38 \\
\hline FGF23 [pg/mL] & $39.43(18.34-70.19)$ & $28.84(16.26-57.56)$ & 0.15 \\
\hline a-Klotho [pg/mL] & $728(507-905)$ & $864(578-1080)$ & 0.51 \\
\hline PTH [pg/mL] & $47.7(30.1-85.1)$ & $67.8(51.9-96.3)$ & $<0.05$ \\
\hline 25-OH-D [ng/mL] & $6.68(4.36-11.96)$ & $9.18(4.65-13.41)$ & 0.48 \\
\hline $25-\mathrm{OH}-\mathrm{D}<10[\mathrm{n}(\%)]$ & $26(66.67)$ & $23(60.53)$ & 0.58 \\
\hline Alphacalcidol use [n (\%)] & $18(48.7)$ & $2(5.1)$ & $<0.001$ \\
\hline CRP [mg/L] & $1.2(0.3-3.0)$ & $1.4(0.5-5.6)$ & 0.26 \\
\hline Fetuin-1 [ng/mL] & $22.8(19.7-26.3)$ & $20.8(16.4-25.1)$ & 0.10 \\
\hline Osteoprotegerin [pmol/L] & $2.35(0.93-3.59)$ & $1.90(1.34-3.05)$ & 0.96 \\
\hline Osteocalcin [ng/ml] & $1.31(0.8-2.04)$ & $2.58(1.34-3.74)$ & $<0.01$ \\
\hline Osteopontin [ng/ml] & $5.8(4.24-7.73)$ & $5.84(4.18-7.89)$ & 0.88 \\
\hline
\end{tabular}

Data present as numbers and frequencies or mean \pm standard deviation or median (lower quartile - upper quartile) if appropriate. SPK, simultaneous pancreas-kidney transplantation; KTA, kidney transplantation alone; BMI, body mass index; HbA1c, glycated hemoglobin; eGFR, estimated glomerular filtration rate; LDL, low density lipoprotein; HDL, high-density lipoprotein; FGF-23, intact fibroblast growth factor 23; PTH, intact parathormon; 25-OH-D, 25-hydroxylated vitamin D; CRP, high sensitive C-reactive protein; MMP, metalloproteinase; IMT, intima-media thickness; PWV, pulse wave velocity. 


\begin{tabular}{|c|c|c|c|}
\hline & $\begin{array}{l}\text { SPK } \\
n=39\end{array}$ & $\begin{array}{l}\text { KTA } \\
n=39\end{array}$ & $\mathbf{p}$ \\
\hline MMP-1 [ng/ml] & $0.20(0.11-0.38)$ & $0.45(0.27-1.97)$ & $<0.01$ \\
\hline MMP-2 [ng/ml] & $4.04(2.59-5.66)$ & $10.44(2.99-17.88)$ & $<0.01$ \\
\hline MMP-3 [ng/ml] & $3.67(2.05-7.24)$ & $14.52(6.72-30.95)$ & $<0.001$ \\
\hline MMP-9 [ng/ml] & $88.4(64.5-183.4)$ & $121.5(96.6-160.6)$ & 0.46 \\
\hline Carotid plaques [n (\%)] & $19(48.7)$ & $11(29.7)$ & 0.01 \\
\hline Absent & $6(15.4)$ & $2(5.4)$ & \\
\hline Non-calcified & $7(18.0)$ & $8(21.6)$ & \\
\hline Sole calcified lesion & $2(5.1)$ & $5(13.5)$ & \\
\hline Few calcified lesions & $5(12.8)$ & $11(29.7)$ & \\
\hline \multicolumn{4}{|l|}{ Massive calcified lesions } \\
\hline IMT [mm] & $0.73 \pm 0.15$ & $0.77 \pm 0.13$ & 0.30 \\
\hline $\mathrm{PWV}[\mathrm{m} / \mathrm{s}]$ & $12.1 \pm 4.1$ & $11.1 \pm 3.9$ & 0.30 \\
\hline \multicolumn{4}{|c|}{$\begin{array}{l}\text { Data present as numbers and frequencies or mean } \pm \text { standard deviation or median (lower quartile - upper quartile) if appropriate. SPK, simultaneous } \\
\text { pancreas-kidney transplantation; KTA, kidney transplantation alone; BMI, body mass index; HbA1c, glycated hemoglobin; eGFR, estimated glomerular } \\
\text { filtration rate; LDL, low density lipoprotein; HDL, high-density lipoprotein; FGF-23, intact fibroblast growth factor 23; PTH, intact parathormon; } 25-\mathrm{OH}-\mathrm{D} \text {, } \\
25 \text {-hydroxylated vitamin D; CRP, high sensitive C-reactive protein; MMP, metalloproteinase; IMT, intima-media thickness; PWV, pulse wave velocity. }\end{array}$} \\
\hline
\end{tabular}

We found higher serum concentration of PTH and total serum calcium in patients in KTA group, whereas serum phosphorus level and plasma concentrations of 25-OH-D, a-Klotho and FGF-23 were similar in both groups (Table 1). The observed differences cannot be explained by lower use of alphacalcidol in our KTA group.

\section{Structural and functional measures of vascular injury}

Ultrasound imaging of carotid arteries revealed a lower occurrence of atherosclerotic plaques (51.3 vs. 70.3\%; $p<0.01)$, especially calcified lesions ( 35.9 vs. $64.9 \% ; p<0.05)$ in the SPK subjects. Nevertheless, IMT and PWV values were similar in both groups (Table 1).

The patients with calcified lesions were significantly older $(50.9 \pm 7.8$ vs. $43.5 \pm 7.3$ years; $p<0.001)$ and were characterized by greater IMT [Me: $0.8(0.7-0.9)$ vs. Me: $0.7(0.6-0.7) \mathrm{mm} ; \mathrm{p}<0.001]$ than the subjects without calcified lesions. Additionally, they were more likely to use statins (42.1 vs. $18.4 \%$; $<0.05$ ). Of note, the difference in median $\mathrm{HbA}_{1 \mathrm{c}}$ concentration [Me: 6.7\% (5.6-8.2\%) in SPK vs. Me: 6.0\% (5.2-7.6\%) in KTA; $p=0.08$ ] and eGFR [61.9 \pm 26.1 in SPK vs. $52.5 \pm$ $21.6 \mathrm{ml} / \mathrm{min} / 1.73 \mathrm{~m}^{2}$ in KTA; $\mathrm{p}=0.09$ ] between the study groups did not reach statistical significance. Similarly, there was no significant difference in OC levels between these groups [Me: $2268(1253-3525)$ vs Me: $1339(828-3034) p g / L, p=0.31$ ] There was a significant positive correlation between increasing plaque score and age $(\tau=0.402 ; p<0.001)$. The subjects with plaque score $\geq 3$ were more likely to use statins [12 (52.2\%) vs $11(20.7 \%) ; p<0.01]$. Nevertheless, there was no significant association between plaque score and eGFR and OC, metalloproteinases or $\mathrm{HbA}_{1 \mathrm{c}}$ levels.

\section{Biomarkers of vascular injury}

Among the circulating markers of vascular wall remodeling, we found significantly lower values of MMP-1, MMP-2, MMP-3 and OC in SPK subjects. In contrast, there were no differences in MMP-9, fetuin-1, OPG and OP levels (Table 1). 
Of all the analyzed biomarkers, only log MMP-1 (Fig. 1), log MMP-2 (Fig. 2) and log MMP-3 (Fig. 3) concentrations were associated with log $\mathrm{HbA}_{1 \mathrm{c}}$ (Table 2). In addition, both log MMP-1 and log MMP-3 were inversely related to eGFR. Log MMP-1 also correlated with log CRP, log TG, and statin-adjusted HDL levels, whereas log MMP-3 correlated with log CRP and log TG (Table 2). Of note, log OPG and log OC were inversely associated only with eGFR. We did not find significant correlations for OP. Notably, there was also a correlation between plasma osteocalcin and PTH concentrations $(\rho=0.33, p<0.01)$.

Table 2

Factors influencing concentrations of circulating markers of vascular remodeling- univariate linear regression analyses.

\begin{tabular}{|c|c|c|c|c|c|c|c|}
\hline Parameter & $\begin{array}{l}\log _{10}\left(\mathrm{HbA}_{1 \mathrm{c}}\right) \\
{[\%]} \\
\mathbf{r}\end{array}$ & $\begin{array}{l}\text { Cholesterol } \\
{[\mathrm{mmol} / \mathrm{l}]} \\
\mathrm{r}\end{array}$ & $\begin{array}{l}\text { LDL } \\
\text { [mmol/l] } \\
r\end{array}$ & $\begin{array}{l}\mathrm{HDL}^{*} \\
{[\mathrm{mmol} / \mathrm{l}]} \\
\mathrm{r}\end{array}$ & $\begin{array}{l}\log _{10}(\mathrm{TG})^{*} \\
{[\mathrm{mmol} / \mathrm{l}]} \\
\mathrm{r}\end{array}$ & $\begin{array}{l}\text { CRP } \\
{[\mathrm{mg} / \mathrm{l}]} \\
\mathrm{r}\end{array}$ & $\begin{array}{l}\text { eGFR } \\
{\left[\mathrm{ml} / \mathrm{min} / 1.73 \mathrm{~m}^{2}\right]} \\
\mathrm{r}\end{array}$ \\
\hline $\begin{array}{l}\log _{10}(\text { Osteoprotegerin } \\
[\mathrm{pmol} / \mathrm{l}])\end{array}$ & - & - & - & - & - & - & $\begin{array}{l}-0.30 \\
p<0.01\end{array}$ \\
\hline $\begin{array}{l}\log _{10}(\text { Osteocalcin }) \\
{[\mathrm{ng} / \mathrm{ml}]}\end{array}$ & - & - & - & - & - & - & $\begin{array}{l}-0.37 \\
p<0.01\end{array}$ \\
\hline Osteopontin [ng/ml] & - & - & - & - & - & - & - \\
\hline $\log _{10}(\mathrm{MMP}-1)[\mathrm{ng} / \mathrm{ml}]$ & $\begin{array}{l}0.42 \\
p<0.001\end{array}$ & - & - & $\begin{array}{l}0.33 \\
p<0.05\end{array}$ & $\begin{array}{l}0.36 \\
p<0.01\end{array}$ & $\begin{array}{l}0.23 \\
p= \\
0.05\end{array}$ & $\begin{array}{l}-0.36 \\
p<0.01\end{array}$ \\
\hline $\log _{10}(\mathrm{MMP}-2)[\mathrm{ng} / \mathrm{ml}]$ & $\begin{array}{l}0.30 \\
p<0.01\end{array}$ & - & - & - & - & - & - \\
\hline $\log _{10}(\mathrm{MMP}-3)[\mathrm{ng} / \mathrm{ml}]$ & $\begin{array}{l}0.49 \\
p<0.001\end{array}$ & - & - & - & $\begin{array}{l}0.38 \\
p<0.01\end{array}$ & $\begin{array}{l}0.26 \\
p< \\
0.05\end{array}$ & $\begin{array}{l}-0.38 \\
p<0.001\end{array}$ \\
\hline $\begin{array}{l}\log _{10}(\mathrm{MMP}-9) \\
[\mathrm{ng} / \mathrm{ml}])\end{array}$ & & - & - & - & - & - & - \\
\hline
\end{tabular}

The multivariate stepwise backward regression analysis revealed that variabilities of MMP-1 and MMP-3 values were explained by $\log \mathrm{HbA}_{1 \mathrm{c}}$, whereas $\mathrm{OC}$ variability by eGFR, only (Table 3 ). 
Table 3

Factors influencing concentrations of circulating markers of vascular remodeling- stepwise backward regression analysis.

$\beta \operatorname{SE}(\beta)$

\begin{tabular}{|c|c|c|c|c|c|}
\hline Parameter & $\begin{array}{l}\log _{10}(M M P-1) \\
{[\mathrm{ng} / \mathrm{ml}]}\end{array}$ & $\begin{array}{l}\log _{10}(M M P-2) \\
{[\mathrm{ng} / \mathrm{ml}]}\end{array}$ & $\begin{array}{l}\log _{10}(\mathrm{MMP}-3) \\
{[\mathrm{ng} / \mathrm{ml}]}\end{array}$ & $\begin{array}{l}\log _{10} \text { (Osteocalcin) } \\
{[\mathrm{ng} / \mathrm{ml}]}\end{array}$ & $\begin{array}{l}\log _{10}(\text { Osteoprotegerin) } \\
{[\mathrm{pmol} / \mathrm{l}]}\end{array}$ \\
\hline \multirow{2}{*}{$\begin{array}{l}\text { eGFR } \\
{\left[10 \mathrm{ml} / \mathrm{min} / 1.73 \mathrm{~m}^{2}\right]}\end{array}$} & \multirow[t]{2}{*}{-} & \multirow[t]{2}{*}{-} & \multirow[t]{2}{*}{-} & $-0.060(0.017)$ & \multirow[t]{2}{*}{-} \\
\hline & & & & $p<0.001$ & \\
\hline \multirow[t]{2}{*}{$\log _{10}\left(\mathrm{HbA}_{1 \mathrm{c}}\right)[\%]$} & $2.415(0.614)$ & - & $2.304(0.473)$ & - & - \\
\hline & \multicolumn{2}{|l|}{$p<0.001$} & \multicolumn{2}{|l|}{$\mathrm{p}<0.001$} & \\
\hline $\log _{10}(\mathrm{CRP})[\mathrm{mg} / \mathrm{l}]$ & - & - & - & - & - \\
\hline $\mathrm{HDL}^{*}[\mathrm{mmol} /]$ & - & - & - & - & - \\
\hline $\log _{10}(\mathrm{TG}) \star[\mathrm{mmol} / \mathrm{l}]$ & - & - & - & - & - \\
\hline
\end{tabular}

\section{Discussion}

The main finding of our present study is the demonstration of significantly lower concentration of circulating metalloproteinases (MMP-1, MMP-2 and MMP-3) in SPK recipients, as compared with KTA patients, which potentially may reflect the beneficial changes in the vascular wall related to the normalization of glucose metabolism. Importantly, multivariate analysis confirmed the independent association of $\mathrm{HbA}_{1 \mathrm{c}}$ levels with MMP-1 and MMP-3 concentrations. Additionally, SPK subjects also presented with lower plasma osteocalcin level, but it was related merely to better kidney graft function.

It has been postulated that restoring of normoglycemia after successful SPK transplantation should be followed by favorable effect on the vascular system, which will compensate the increased risk of surgical and infectious complications, including death, related to combined organ transplantation. However, taking into account the advanced vascular wall damage already present at the time of transplantation, being a consequence of several decades of diabetes and subsequent uremia, the expected vascular improvement after SPK is difficult to demonstrate in cohort studies. Additionally, the lack of such evidence can also be explained by non-optimal metabolic efficiency in a significant proportion of transplanted pancreas, which may result from their fragmentary thrombosis, and even more from weight gain and increasing insulin resistance after transplantation [21, 22]. In line with the above, in the present study the surrogate of arterial stiffness (PWV) and carotid atherosclerosis were shown to be similar in SPK and KTA patients. Nonetheless, the analysis of vascular wall remodeling biomarkers, showed significant correlations between $\mathrm{HbA}_{1 \mathrm{c}}$ and MMP-1, MMP-2 and MMP-3 plasma levels, confirmed by multivariate analysis for MMP-1 and MMP-3. This indirect evidence supports the expected improvement in vascular wall metabolism related to normal glucose metabolism control in SPK patients.

MMP-2 and MMP-9 are considered to be main enzymes that degrade collagen type IV, the key component of extracellular matrix which determines the structure of vessels and glomerular base membranes [23]. Previously, the upregulation of MMP2 and MMP-9 was shown in arterial vasculature of diabetic CKD patients and turned out to be correlated with arterial stiffness [24], whereas a MMP-3 gene polymorphism (rs3025058) was associated with subclinical markers of coronary atherosclerosis and IMT progression in type 2 diabetes [25]. Moreover, several advanced glycation end-products were associated with plasma levels of MMP-2 and MMP-3 in T1D individuals [26]. Notably, in line with our present findings, Reine et al. described beneficial effects of successful SPK, as compared to KTA, on the kidney graft extracellular matrix structure in 
approximately 10-year observation in T1D patients [27]. We may hypothesize that the long-term restoration of normoglycemia results in favorable MMPs profile, which probably reflects the slowing of vascular system damage (diabetic vasculopathy/remodeling). Our finding could be supported by long-term observational studies analyzing the evolution of vascular function parameters during more than 10-year follow-up period after SPK.

When considering the potential association between the metabolism of glucose and established biochemical markers of vascular calcification, none of them turned out to be associated with $\mathrm{HbA}_{1 \mathrm{c}}$ level. Although plasma osteocalcin levels were shown to be significantly lower in SPK patients, it was attributed to better kidney graft function and lower serum PTH concentration, but not to $\mathrm{HbA}_{1 \mathrm{c}}$ blood level in this group. To date, the only study in small insulin-independent SPK cohort reported mildly elevated osteocalcin levels in $45 \%$ of the patients, with similar association with PTH [28]. Previously, osteocalcin has been found in calcified atherosclerotic plaques [29]. On the other hand, OC has been shown to stimulate insulin secretion by pancreas and glucose uptake in the adipose tissue [30]. Nonetheless, the utility of OC as a biomarker is still discussed in conflicting studies [30].

The main limitation of this study is its low number of participants. However, we included all eligible SPK patients attending our out-patient clinic, who gave their consent to participate in the research. Additionally, we recruited the KTA group based on 2 transplant centers, due to the low number of T1D patients in whom KTA was performed. Moreover, in the effort to improve the study groups match in comparison to our original analysis [11], especially with regard to age and the post-transplant follow-up period, we reassessed the eligible SPK subjects again and repeated all biochemical parameters using the same methodology. It should be stressed that the enrollment of T1D patients after KTA as a control group eliminates the bias of potential metabolic memory related to uremic milieu.

\section{Conclusion}

In, our study we have demonstrated that SPK recipients are characterized by a favorable profile of circulating matrix metalloproteinases, in comparison to KTA subjects with T1D. This potential vasoprotective effect of SPK transplantation seems to be mediated mainly by the normalization of glucose metabolism.

\section{Abbreviations}

SPK simultaneous pancreas-kidney transplantation

T1D type 1 diabetes

PWV pulse wave velocity

IMT intima-media thickness

KTA kidney transplantation alone

MMPs matrix metalloproteinases

OC osteocalcin

OP osteopontin

eGFR estimated glomerular filtration rate

ESRD end-stage renal disease

CKD chronic kidney disease 
BMI body mass index

$\mathrm{HbA}_{1 \mathrm{c}}$ glycated hemoglobin

EDTA ethylenediaminetetraacetic acid

ELISA enzyme-linked immunosorbent assay

CRP C-reactive protein

MMP-9 matrix metalloproteinase 9

MMP-1 matrix metalloproteinase 1

MMP-2 matrix metalloproteinase 2

MMP-3 matrix metalloproteinase 3

FGF23 fibroblast growth factor-23

PTH parathyroid hormone

ECLIA electrochemiluminescence method

BP blood pressure

SD standard deviation

OPG osteoprotegerin

TG triglycerides

HDL high-density lipoprotein

LDL low density lipoprotein

25-OH-D 25-hydroxylated vitamin D

\section{Declarations}

\section{Ethics approval and consent to participate}

The study protocol was approved by Bioethics Committee of the Medical University of Silesia in Katowice (KNW/0022/KB1/151/12) and each participant gave informed consent.

\section{Consent for publication}

All study patients provided written informed consent for participation, and all data were further analyzed anonymously.

\section{Availability of data and materials}

The datasets analyzed during the current study are available from the corresponding author on reasonable request.

\section{Competing interests}

The authors declare that they have no competing interests. 


\section{Funding}

This research project was funded by National Science Centre, Poland (OPUS 5; Grant No. 2013/09/B/NZ5/00258).

\section{Authors' contributions}

$\mathrm{JC}$ designed the study and contributed in writing the manuscript. AK participated in the investigation, extracted and analyzed the data, and was a major contributor in writing the manuscript. JZ designed the study and supervised the investigation. TF participated in the laboratory work. DK, PK, AK-S, MAK, APK, DBK and JK participated in the investigation. AJO analyzed the data and participated in writing the manuscript. PC participated in the statistical analysis. RK, MK, AW and LC supervised the investigation and critically reviewed the original draft. All authors read and approved the final manuscript.

\section{Acknowledgements}

The authors thank Mrs. Agata Zimowicz and Mrs. Izabela Białas for their valuable technical support.

\section{References}

1. Lindahl JP, Hartmann A, Horneland R, Holdaas H, Reisaeter AV, Midtvedt K, et al. Improved patient survival with simultaneous pancreas and kidney transplantation in recipients with diabetic end-stage renal disease. Diabetologia. 2013;56:1364-71.

2. Morath C, Zeier M, Dohler B, Schmidt J, Nawroth PP, Opelz G. Metabolic control improves long-term renal allograft and patient survival in type 1 diabetes. J Am Soc Nephrol. 2008;19:1557-63.

3. Luan FL, Miles CD, Cibrik DM, Ojo AO. Impact of simultaneous pancreas and kidney transplantation on cardiovascular risk factors in patients with type 1 diabetes mellitus. Transplantation. 2007;84:541-4.

4. La Rocca E, Fiorina P, Di Carlo V, Astorri E, Rossetti C, Lucignani G, et al. Cardiovascular outcomes after kidney-pancreas and kidney-alone transplantation. Kidney Int. 2001;60:1964-71.

5. Henry RM, Kostense PJ, Spijkerman AM, Dekker JM, Nijpels G, Heine RJ, et al. Arterial stiffness increases with deteriorating glucose tolerance status: the Hoorn Study. Circulation. 2003;107:2089-95.

6. Moe SM, O'Neill KD, Duan D, Ahmen S, Chen NX, Leapman SB, et al. Medial artery calcification in ESRD patients is associated with deposition of bone matrix proteins. Kidney Int. 2002;61:638-47.

7. Yki-Jarvinen H, Westerbacka J. Insulin resistance, arterial stiffness and wave reflection. Adv Cardiol. 2007;44:252-60.

8. Chen NX, Moe SM. Arterial calcification in diabetes. Curr Diab Rep. 2003;3:28-32.

9. Khairoun M, de Koning EJP, van den Berg BM, Lievers E, de Boer HC, Schaapherder AFM, et al. Microvascular damage in type 1 diabetic patients is reversed in the first year after simultaneous pancreas-kidney transplantation. Am J Transplant. 2013;13:1272-81.

10. Ziaja J, Kowalik AP, Kolonko A, Kamińska D, Owczarek AJ, Kujawa-Szewieczek A, et al. Type I diabetic patients have better endothelial function after simultaneous pancreas-kidney transplantation than after kidney transplantation with continued insulin therapy. Diab Vasc Dis Res. 2018;15:122-30.

11. Stadler M, Theuer E, Anderwald C, Hanusch-Enserer U, Auinger M, Bieglmayer C, et al. Persistent arterial stiffness and endothelial dysfunction following successful pancreas-kidney transplantation in type 1 diabetes. Diab Med.

2009;26:1010-8.

12. Biesenbach G, Konigsrainer A, Gross C, Margreiter R. Progression of macrovascular disease is reduced in type 1 diabetic patients after more than 5 years successful combined pancreas-kidney transplantation in comparison to kidney transplantation alone. Transplant Int. 2005;18:1054-60.

13. Morath C, Zeier M, Dohler B, Schmidt J, Nawroth PP, Schwenger V, et al. Transplantation of the type 1 diabetic patient: the long-term benefit of a functioning pancreas allograft. Clin J Am Soc Nephrol. 2010;5:549-52. 
14. Garcia-Fernandez N, Jacobs-Cacha C, Mora-Gutierrez JM, Vergara A, Orbe J, Soler MJ. Matrix metalloproteinases in diabetic kidney disease. J Clin Med. 2020;9:472. doi:10.3390/jcm9020472.

15. Ruddy JM, Ikonomidis JS, Jones JA. Multidimensional contribution of matrix metalloproteinases to atherosclerotic plaque vulnerability: multiple mechanisms of inhibition to promote stability. J Vasc Res. 2016;53:1-16.

16. Peeters SA, Engelen L, Buijs J, Chaturvedi N, Fuller JH, Jorsal A, et al. Circulating matrix metalloproteinases are associated with arterial stiffness in patients with type 1 diabetes: pooled analysis of three cohort studies. Cardiovasc Diabetol. 2017;16:139. doi:10.1186/s12933-017-0620-9.

17. Peeters SA, Engelen L, Buijs J, Jorsal A, Parving H-H, Tarnow L, et al. Plasma matrix metalloproteinases are associated with incident cardiovascular disease an all-cause mortality in patients with type 1 diabetes: a 12-year follow-up study. Cardiovasc Diabetol. 2017;16:55. doi:10.1186/s12933-017-053901.

18. Hecht E, Freise C, v Websky K, Nasser H, Kretzschmar N, Stawowy P, et al. The matrix metalloproteinases 2 and 9 initiate uraemic vascular calcifications. Nephrol Dial Transplant. 2016;31:789-97.

19. Lee SJ, Lee I-K, Jeon J-H. Vascular calcification - new insights into its mechanism. Int J Mol Sci. 2020;21:2685. doi:10.3390/ijms21082685.

20. Rusińska A, Płudowski P, Walczak M, Borszewska-Kornacka MK, Bossowski A, Chlebna-Sokół D, et al. Vitamin D Supplementation Guidelines for General Population and Groups at Risk of Vitamin D Deficiency in PolandRecommendations of the Polish Society of Pediatric Endocrinology and Diabetes and the Expert Panel With Participation of National Specialist Consultants and Representatives of Scientific Societies- 2018 Update. Front Endocrinol (Lausanne). 2018;9:246. doi:10.3389/fendo.2018.00246.

21. De Mier VP-R, Navarro Cabello MD, Martinez Vaquera S, Lopez-Andreu M, Aguera Morales ML, Rodriguez-Benot A, et al. Index high insulin resistance in pancreas-kidney transplantation contributes to poor long-term survival of the pancreas graft. Transplant Proc. 2015;47:117-9.

22. Mora M, Ricart MJ, Casamitjana R, Astudillo E, Lopez I, Jimenez A, et al. Pancreas and kidney transplantation: long-term endocrine function. Clin Transplant. 2010;24:E236-40.

23. Dimas GG, Didangelos TP, Grekas DM. Matrix gelatinases in atherosclerosis and diabetic nephropathy: progress and challenges. Curr Vasc Pharmacol. 2017;15:557-65.

24. Chung AWY, Clarice Yang HH, Sigrist MK, Brin G, Chum E, Gourlay WA, et al. Matrix metalloproteinase-2 and - 9 exacerbate arterial stiffening and angiogenesis in diabetes and chronic kidney disease. Cardiovasc Res. 2009;84:494504.

25. Plescovic A, Letonja MS, Vujkovac AC, Starcevic JN, Caprnda M, Curilla E, et al. Matrix metalloproteinase-3 gene polymorphism (rs3025058) affects markers of atherosclerosis in type 2 diabetes mellitus. Vasa. 2017;46:363-9.

26. Peeters SA, Engelen L, Buijs J, Theilade S, Rossing P, Schalkwijk CG, et al. Associations between advanced glycation endproducts and matrix metalloproteinases and its inhibitor in individuals with type 1 diabetes. J Diabetes Complications. 2018;32:325-9.

27. Reine TM, Kolseth IBM, Meen AJ, Lindahl JP, Jenssen TG, Reinholt FP, et al. Effects of restoring normoglycemia in type 1 diabetes on inflammatory profile and renal extracellular matrix structure after simultaneous pancreas and kidney transplantation. Diab Res Clin Pract. 2015;107:46-53.

28. Smets YFC, van der Pijl JW, de Fijter JW, Ringers J, Lemkes HHPJ, Hamdy NAT. Low bone mass and high incidence of fractures after successful simultaneous pancreas-kidney transplantation. Nephrol Dial Transplant. 1998;13:1250-5.

29. Levy RJ, Gundberg C, Scheinman R. The identification of the vitamin k-dependent bone protein osteocalcin as one of the $\mathrm{Y}$-carboxyglutamic acid containing proteins present in calcified atherosclerotic plaque and mineralized heart valves. Atherosclerosis. 1983;46:49-56.

30. Evrard S, Delanaye P, Kamel S, Cristol J-P, Cavalier E. Vascular calcification: from pathophysiology to biomarkers. Clin Chim Acta. 2015;438:401-14. 
Figures

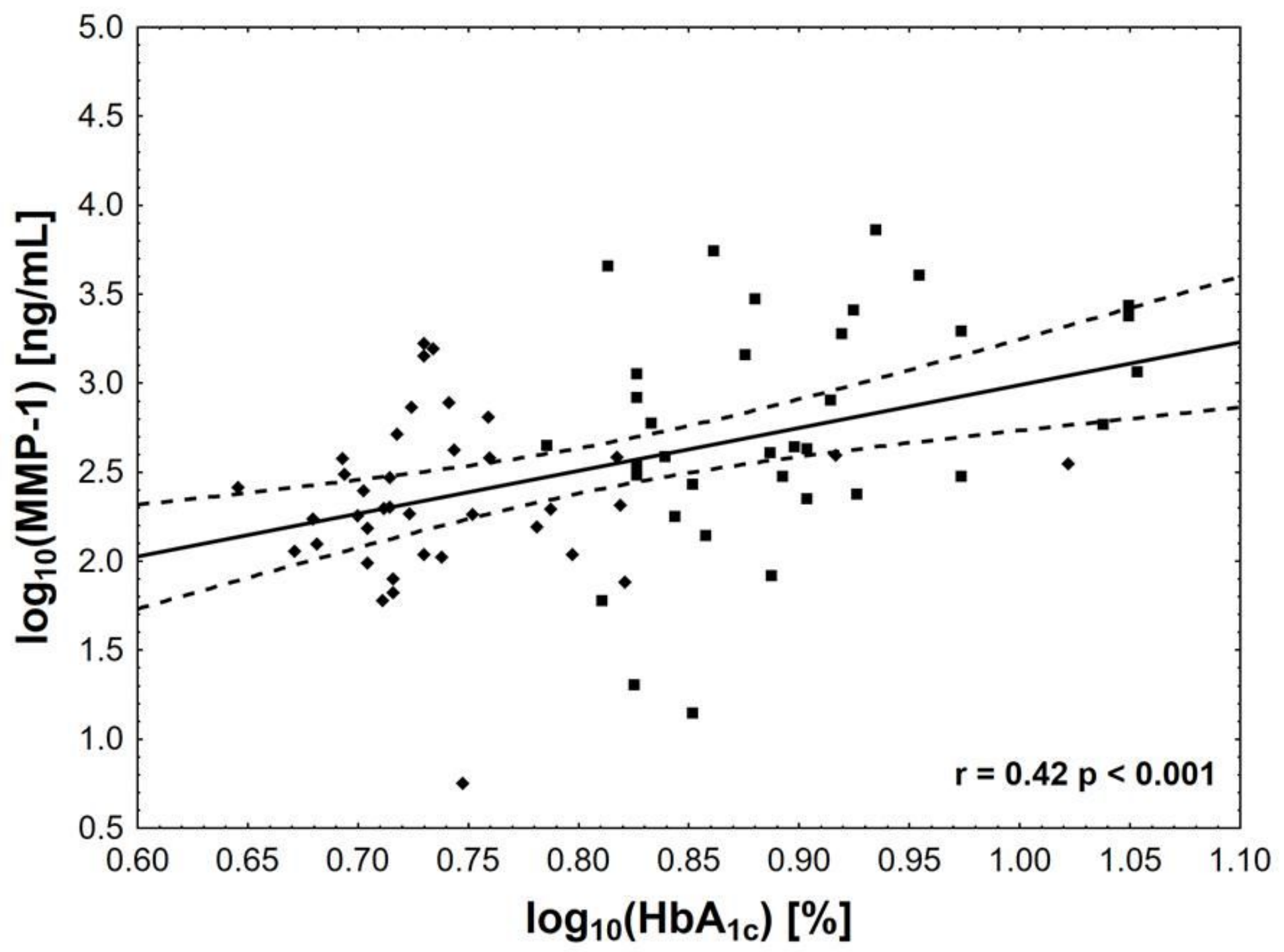

Figure 1

The associations between HbA1c concentration and MMP-1 activity. 


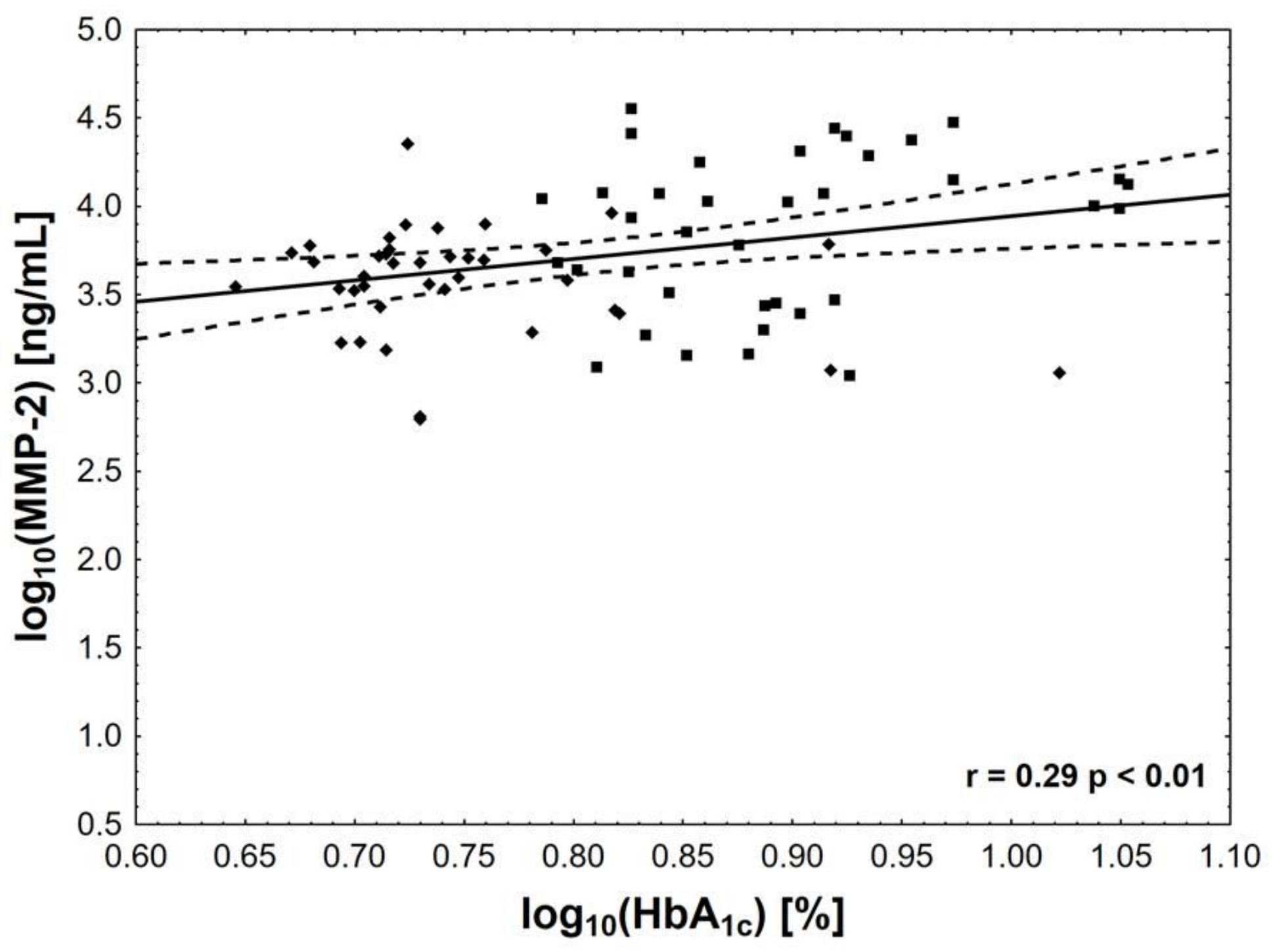

Figure 2

The associations between HbA1c concentration and MMP-2 activity. 


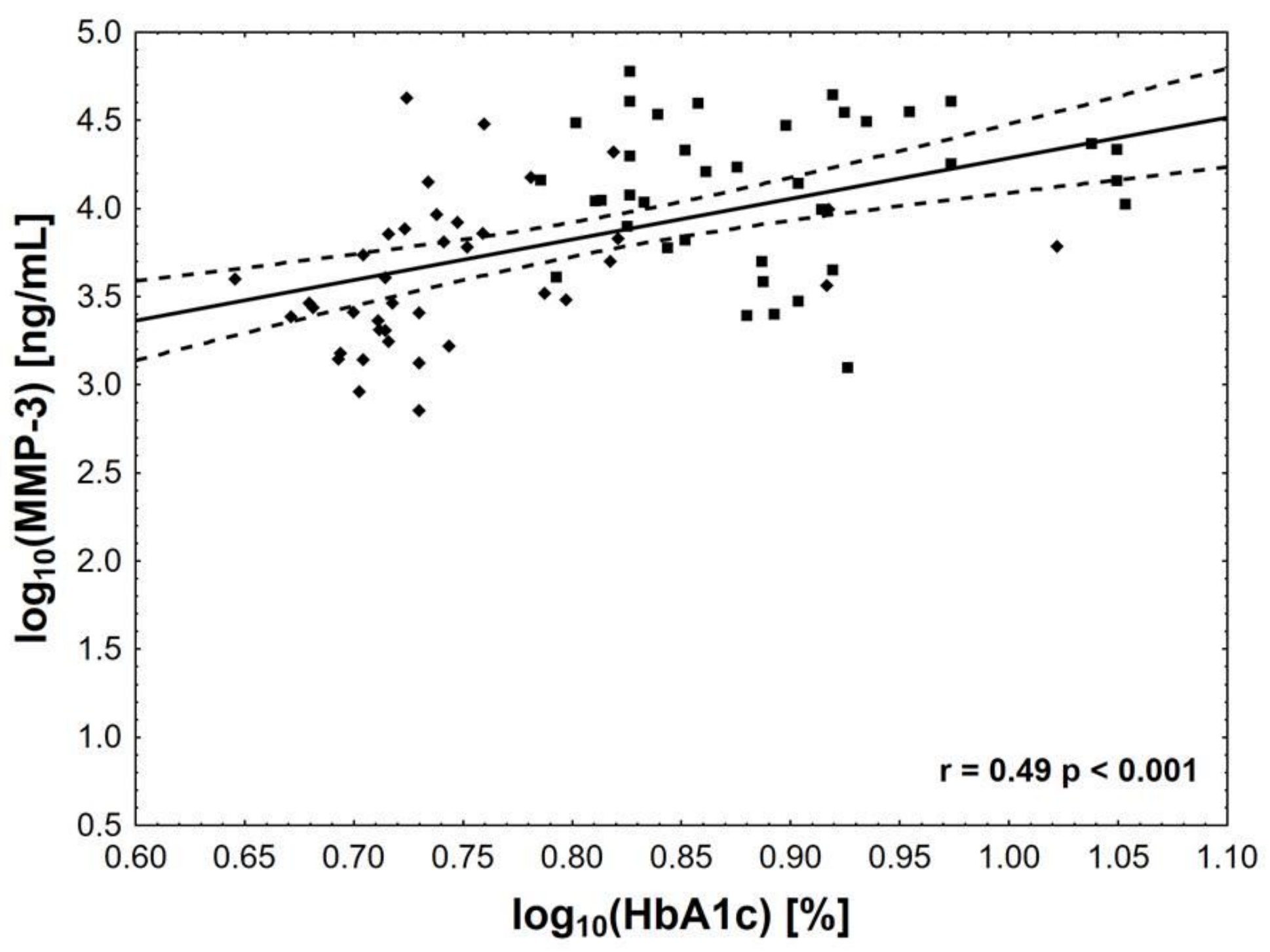

Figure 3

The associations between $\mathrm{HbA} 1 \mathrm{c}$ concentration and MMP-3 activity. The value of log $\mathrm{HbA} 1 \mathrm{c}$ of 0,78 corresponds to $\mathrm{HbA1c}$ level $=6.0 \%, \log \mathrm{HbA} 1 \mathrm{c}$ of $0.9-$ to $\mathrm{HbA} 1 \mathrm{c}$ level $=8.0 \%$ and $\log \mathrm{HbA} 1 \mathrm{c}$ of $1.0-$ to $\mathrm{HbA} 1 \mathrm{c}$ level $=10 \%$. 